\title{
Review of Griffin, M. M., \& Zinskie, C. D. (Eds.). (2021). Social media: Influences on education. Information Age Publishing
}

\author{
K. Bret Staudt Willet ${ }^{1}$
}

Published online: 24 February 2022

(c) Association for Educational Communications \& Technology 2022

Social Media: Influences on Education (Griffin \& Zinskie, 2021) is a short volume of 10 edited chapters that provide an introduction to how social media are being used in education currently. This book is part of a larger series from Information Age Publishing called Current Perspectives on Cognition, Learning, and Instruction. The editors of this volume note that their specific interest is in teacher education. There is a high degree of interest on the topic of social media and teacher education, as exhibited by the editors receiving more than 50 proposals that resulted in the 10 published chapters.

Situated in a context of substantial prior research into social media and teacher education and a growing community around this topic, Social Media: Influences on Education does offer a contribution as a helpful overview and introduction to the larger conversation. The chapters enclosed offer accessible and interesting glimpses into various uses of social media. In their introduction, the editors provide a helpful summary paragraph of each chapter, so I will not reproduce that in this review. Readers should feel confident that the editors' summaries do provide a succinct overview of the chapters.

The book is divided into four sections: (1) Youth and College Students, (2) Professional Development in Content Areas, (3) Higher Education Learning, and (4) Social Justice and Activism. These sections are somewhat confusing, however. There is not a consistent thread across the sections, as two (2 and 4 ) are organized by categories of social media use, and the other two ( 1 and 3 ) by educational level. This is further complicated in that there are significant overlaps between sections. For instance, five chapters (i.e., half of all) focus on undergraduate students, but these chapters are not all included in Section 3: Higher Education Learning but are spread throughout the first three sections. From my own reading of this volume, I propose that readers consider

K. Bret Staudt Willet

bret.staudtwillet@fsu.edu

1 Florida State University, Tallahassee, FL, USA three thematic sections (and a reading order) organized by the implications of using social media in education:

- Section 1: Overview of social media in education (Chapters 8, 9, and 3);

- Section 2: Cautions for social media use among undergraduate students (Chapters 7, 6, 2, and 1); and

- Section 3: Possibilities for social media and inservice teachers' professional learning (Chapters 4, 5, and 10)

To help readers home in on their specific interests and to make the strengths of Social Media: Influences on Education more overt, I have created a summary table of the ten chapters:

\begin{tabular}{|c|c|c|c|}
\hline Chapter & $\begin{array}{l}\text { Education } \\
\text { Level }\end{array}$ & Methodology & Implications \\
\hline $\begin{array}{l}\text { 1. Social Media } \\
\text { Use and Cyber- } \\
\text { Harassment } \\
\text { Among Under- } \\
\text { graduate College } \\
\text { Students }\end{array}$ & Undergraduate & $\begin{array}{l}\text { Survey } \\
\qquad(n=789 \\
\text { students })\end{array}$ & $\begin{array}{l}\text { Cautions for } \\
\text { social media } \\
\text { use }\end{array}$ \\
\hline $\begin{array}{l}\text { 2. Investigating } \\
\text { Intentionality } \\
\text { in Preservice } \\
\text { Teachers' Per- } \\
\text { sonal and Profes- } \\
\text { sional Social } \\
\text { Networking Site } \\
\text { Usage }\end{array}$ & $\begin{array}{l}\text { Undergraduate } \\
\text { (Preservice } \\
\text { Teachers) }\end{array}$ & $\begin{array}{l}\text { Survey } \\
\quad(n=143 \\
\text { students })\end{array}$ & $\begin{array}{l}\text { Cautions for } \\
\text { social media } \\
\text { use }\end{array}$ \\
\hline $\begin{array}{l}\text { 3. Social Media } \\
\text { Use Among 9- } \\
\text { to } 11 \text {-Year-Old } \\
\text { Children and } \\
\text { School Princi- } \\
\text { pals' Leadership } \\
\text { Practices }\end{array}$ & Elementary & $\begin{array}{l}\text { Survey ( } n=36 \\
\text { students), } \\
\text { focus groups } \\
\text { ( } n=15 \text { stu- } \\
\text { dents), and } \\
\text { interviews } \\
(n=2 \text { princi- } \\
\text { pals) }\end{array}$ & $\begin{array}{l}\text { Overview of } \\
\text { social media } \\
\text { in education }\end{array}$ \\
\hline
\end{tabular}




\begin{tabular}{|c|c|c|c|}
\hline Chapter & $\begin{array}{l}\text { Education } \\
\text { Level }\end{array}$ & Methodology & Implications \\
\hline $\begin{array}{l}\text { 4. "Sharing is Car- } \\
\text { ing": Extending } \\
\text { the Professional } \\
\text { Learning Com- } \\
\text { munity Using } \\
\text { Social Media }\end{array}$ & $\begin{array}{c}\text { Inservice } \\
\text { Teachers }\end{array}$ & $\begin{array}{l}\text { Interviews } \\
\quad(\mathrm{n}=26 \\
\text { teachers) and } \\
\text { content anal- } \\
\text { ysis }(n=553 \\
\text { Facebook } \\
\text { group } \\
\text { threads) }\end{array}$ & $\begin{array}{l}\text { Possibilities } \\
\text { for social } \\
\text { media and } \\
\text { teacher' } \\
\text { professional } \\
\text { learning }\end{array}$ \\
\hline $\begin{array}{l}\text { 5. English } \\
\text { Language Arts } \\
\text { Teachers' Expe- } \\
\text { riences Using } \\
\text { Social Media in } \\
\text { Instruction }\end{array}$ & $\begin{array}{l}\text { Inservice } \\
\text { Teachers }\end{array}$ & $\begin{array}{l}\text { Interview } \\
\quad(n=9 \text { teach- } \\
\text { ers })\end{array}$ & $\begin{array}{l}\text { Possibilities } \\
\text { for social } \\
\text { media and } \\
\text { teacher' } \\
\text { professional } \\
\text { learning }\end{array}$ \\
\hline $\begin{array}{l}\text { 6. “I Just Saw it } \\
\text { on Facebook, } \\
\text { So That Isn’t } \\
\text { True”: How the } \\
\text { Omnipresence } \\
\text { of Social Media } \\
\text { Complicates } \\
\text { History Educa- } \\
\text { tion }\end{array}$ & $\begin{array}{l}\text { Undergraduate } \\
\text { (Preservice } \\
\text { Teachers) }\end{array}$ & $\begin{array}{l}\text { Observations } \\
\text { and content } \\
\text { analysis of } \\
\text { students' } \\
\text { class materi- } \\
\text { als ( } n=82 \\
\text { students) }\end{array}$ & $\begin{array}{l}\text { Cautions for } \\
\text { social media } \\
\text { use }\end{array}$ \\
\hline $\begin{array}{l}\text { 7. Exploring } \\
\text { Learner-Content } \\
\text { Interactions in } \\
\text { a University } \\
\text { Course Through } \\
\text { Social Media } \\
\text { Use }\end{array}$ & $\begin{array}{l}\text { Undergraduate } \\
\text { (Preservice } \\
\text { Teachers) }\end{array}$ & $\begin{array}{l}\text { Surveys, } \\
\text { interviews, } \\
\text { observations, } \\
\text { and content } \\
\text { analysis of } \\
\text { students' } \\
\text { class materi- } \\
\text { als ( } n=12 \\
\text { students) }\end{array}$ & $\begin{array}{l}\text { Cautions for } \\
\text { social media } \\
\text { use }\end{array}$ \\
\hline $\begin{array}{l}\text { 8. The Relation- } \\
\text { ship Between } \\
\text { Social Network } \\
\text { Sites and Per- } \\
\text { ceived Learning } \\
\text { and Satisfaction } \\
\text { for Educational } \\
\text { Purposes }\end{array}$ & Undergraduate & $\begin{array}{l}\text { Systematic } \\
\text { literature } \\
\text { review and } \\
\text { meta-analysis } \\
(n=31 \text { arti- } \\
\text { cles })\end{array}$ & $\begin{array}{c}\text { Overview of } \\
\text { social media } \\
\text { in education }\end{array}$ \\
\hline $\begin{array}{l}\text { 9. Learning } \\
\text { About Social } \\
\text { Justice Through } \\
\text { Social Media: } \\
\text { A Review of the } \\
\text { Literature }\end{array}$ & $\begin{array}{l}\text { PreK to Higher } \\
\text { Education }\end{array}$ & $\begin{array}{l}\text { Systematic } \\
\text { literature } \\
\text { review } \\
(n=43 \text { arti- } \\
\text { cles })\end{array}$ & $\begin{array}{l}\text { Overview of } \\
\text { social media } \\
\text { in education }\end{array}$ \\
\hline $\begin{array}{l}\text { 10. Social Media } \\
\text { Connections } \\
\text { Between Educa- } \\
\text { tors and Advo- } \\
\text { cacy Networks: } \\
\text { The Twitter } \\
\text { Activity of } \\
\text { Teacher Activist } \\
\text { Groups }\end{array}$ & $\begin{array}{l}\text { Inservice } \\
\text { Teachers }\end{array}$ & $\begin{array}{l}\text { Content analy- } \\
\text { sis ( } n=800 \\
\text { tweets) }\end{array}$ & $\begin{array}{l}\text { Possibilities } \\
\text { for social } \\
\text { media and } \\
\text { teacher' } \\
\text { professional } \\
\text { learning }\end{array}$ \\
\hline
\end{tabular}

This overview table highlights three important strengths of Social Media: Influences on Education. First, these chapters demonstrate social media research conducted with a range of learners, from PreK to inservice teachers. Second, this volume does well to emphasize cautions of social media use in education in addition to the possibilities, a consideration that should not be taken for granted in educational technology research (Selwyn, 2011). Third, the studies incorporate a wide variety of foundational methodologies that can be applied to social media research. Indeed, these chapters provide models that other researchers could follow. For instance, Chapter 8 followed and reported PRISMA guidelines (Moher et al., 2009), considered the best practice in conducting a systematic literature review. Also, Chapter 7 provided numerous qualitative data sources for a strong multiple case study, and Chapters 4 and 10 provided examples of hand-coded content analysis for social media data from Facebook and Twitter, respectively.

However, the overview table also reveals several pieces missing from the book. For instance, not all educational levels or stakeholders are represented; specifically, there are no studies focusing on middle school students, high school students, school administrators, or policy makers. Although the editors, in the Introduction, rightly note the international nature of the studies, the span of contexts is limited: six chapters were based in the U.S., one in Canada, and one in Sweden. This means that perspectives on social media use in education from the Global South are notably absent.

Finally, although the chapters in this book introduce foundational methods, these approaches to social media inquiry do not fully convey the rich variety of contemporary tools for data collection and analysis present in recent literature. For instance, Boer and Asino (2022) recently took an ethnographic approach to understand how teachers in Namibia responded to COVID-19 challenges, such as using the social media platform WhatsApp. Santoveña Casal (2019) took an inferential statistical approach to understand impacts of social media use on academic performance. Kimmons and Veletsianos (2018) wrote a helpful overview of internet data mining methods for educational research. Rosenberg et al. (2020) collected tweets and used an inferential social network analysis approach to model selection and influence in conversations about the Next Generation Science Standards (NGSS). Arslan et al. (2021) employed natural language processing and machine learning algorithms along with quantitative multilevel models to understand why some topics persist in the longstanding \#Edchat conversation on Twitter. These are just a few examples of recent trends in social media methods that may be of interest to readers who are ready to move beyond Social Media: Influences on Education.

\section{Conclusion}

The title of the book suggests this volume will address the influence of social media on education. However, the book would be better characterized as a survey of a relatively new 
educational technology, social media, with emphasis on its use in teacher education. Strengths of this volume include showcasing social media applications and research among a wide range of learners, emphasizing cautions as well as benefits of social media use in education, and introducing foundational methodologies of social media research.

Social Media: Influences on Education provides a useful starting point for many readers new to the subject. Some, however, may benefit from more background, such as a clear conceptualization and definition of "social media." These readers may benefit from referencing Humphreys' (2016) helpful guide, which defined this set of tools and platforms generally as media being used socially and then offered categories including social networking sites, media sharing, news feeds, and so on. Other readers may wish to situate social media in an historic perspective on educational technologies that have long promised to personalize learning and deliver responsive feedback, going back to at least the nineteenth-century (Watters, 2021). Social media are worth contemporary consideration, and their investigation will undoubtedly be followed by books written on the influences of artificial intelligence (AI) and virtual reality (VR) on education.

\section{References}

Arslan, O., Xing, W., Inan, F. A., \& Du, H. (2021). Understanding topic duration in twitter learning communities using data mining. Journal of Computer Assisted Learning. https://doi.org/10. $1111 /$ jcal.12633
Boer, P. J., \& Asino, T. I. (2022). Learning design experiences of the Namibian teachers during the COVID-19 pandemic: An ethnographic perspective. TechTrends, 66, 29-38. https://doi.org/10. 1007/s11528-021-00684-8

Griffin, M. M., \& Zinskie, C. D. (Eds.). (2021). Social media: Influences on education. Information Age Publishing.

Humphreys, A. (2016). Social media: Enduring principles. Oxford University Press.

Kimmons, R., \& Veletsianos, G. (2018). Public internet data mining methods in instructional design, educational technology, and online learning research. TechTrends, 62, 492-500. https://doi. org/10.1007/s11528-018-0307-4

Moher, D., Liberati, A., Tetzlaff, J., \& Altman, D. G. (2009). ReprintPreferred reporting items for systematic reviews and meta-analyses: The PRISMA statement. Physical Therapy, 89(9), 873-880. https://doi.org/10.1093/ptj/89.9.873

Rosenberg, J. M., Reid, J. W., Dyer, E. B., Koehler, M. J., Fischer, C., \& McKenna, T. J. (2020). Idle chatter or compelling conversation? The potential of the social media-based \#NGSSchat network for supporting science education reform efforts. Journal of Research in Science Teaching, 57(9), 1322-1355. https://doi.org/10.1002/ tea. 21660

Santoveña Casal, S. (2019). The impact of social media participation on academic performance in undergraduate and postgraduate students. The International Review of Research in Open and Distance Learning, 20(1). https://doi.org/10.19173/ irrodl.v20i1.3751

Selwyn, N. (2011). In praise of pessimism - The need for negativity in educational technology. British Journal of Educational Technology, 42(5), 713-718. https://doi.org/10.1111/j.1467-8535.2011. 01215.x

Watters, A. (2021). Teaching machines: The history of personalized learning. MIT Press.

Publisher's Note Springer Nature remains neutral with regard to jurisdictional claims in published maps and institutional affiliations. 